\title{
Distribution, Enrichment and Ecological Risk Assessment of Six Elements in Bed Sediments of a Tropical River, Chottanagpur Plateau: A Spatial and Temporal Appraisal
}

\author{
Kumar Manoj, Pratap Kumar Padhy* \\ Department of Environmental Studies, Institute of Science, Visva-Bharati University, Santiniketan, India \\ Email: ${ }^{*}$ pkpadhy@visva-bharati.ac.in
}

Received 17 August 2014; revised 15 September 2014; accepted 11 October 2014

Copyright @ 2014 by authors and Scientific Research Publishing Inc.

This work is licensed under the Creative Commons Attribution International License (CC BY). http://creativecommons.org/licenses/by/4.0/

\begin{abstract}
Distribution and enrichment of six elements (iron, zinc, copper, lead, cadmium and manganese) in surface bed sediments, collected from seventeen selected locations during pre-monsoon and postmonsoon periods, of the tropical Chottanagpur plateau river Subarnarekha along with the ecological risks involved were investigated. Owing to the rich occurrence of mineral resources, the Subarnarekha river basin has a large scale presence of industrial and mining units especially in the Indian State of Jharkhand. An assessment, which involved examining distribution pattern of elements, comparative studies with sediment quality guidelines (SQGs) and geochemical background values and a sequential and integrated index analyses approach (containing contamination factor (CF), pollution load index (PLI), contamination degree (CD), enrichment factor (EF), geo-accumulation index (Igeo) and potential ecological risk index (PERI)), was followed to estimate enrichment and risks of elements in the bed sediments. Sediments collected from areas having abundance of population, industrial conglomerates and mining units recorded elevated element concentrations, which exceeded SQGs, and significantly higher values of CF, CD, PLI, EF, Igeo and PERI. Cadmium demonstrated surprising regularity in its enrichment; contributed most to the ecological risks; and high toxicity risks due to cadmium exceeded $64 \%$ of the sites. Moreover, chronic exposures of other elements would also lead to similar ecological risks. In addition to revealing potential ecological risks due to cadmium and other elements our investigation markedly highlighted anthropogenic control over sediment quality deterioration and some immediate sediment quality management strategies are needed to remediate and control river bed contamination.
\end{abstract}

\footnotetext{
${ }^{*}$ Corresponding author.

How to cite this paper: Manoj, K. and Padhy, P.K. (2014) Distribution, Enrichment and Ecological Risk Assessment of Six Elements in Bed Sediments of a Tropical River, Chottanagpur Plateau: A Spatial and Temporal Appraisal. Journal of Environmental Protection, 5, 1419-1434. http://dx.doi.org/10.4236/jep.2014.514136
} 


\section{Keywords}

\section{Anthropogenic Impacts, Ecological Risk Index, Geo-Accumulation Index, Trace Elements, Pollution Load Index, Sediment Contamination}

\section{Introduction}

Developing countries in the last few decades have undergone rapid industrialization, urbanization, population growth and change in land use pattern. These factors have directly influenced the aquatic systems and contributed to their deterioration in quality. In India, most of the industrial conglomerates and urban areas, being located along the river basins, discharge their wastes into the river streams. In addition, application of pesticides and chemical fertilizers in agricultural fields, urban runoffs and atmospheric depositions also contribute to the pollution of water bodies. Sediments are regarded as sensitive indicators for monitoring toxic and hazardous contaminants entering aquatic environments [1]. Though, quality assessment and monitoring of natural streams have become regular part of the national river conservation plans, investigations on sediment quality also require equal attention as they are potential sources for mobility and bioavailability of contaminants like trace elements in the aquatic systems [2]-[4]. A thorough analysis of nature of sediments is required to identify the natural lithogenic and anthropogenic sources of contaminants [5] [6]. Investigation of elements distribution in sediments is also important to understand their behaviour and transport in the fluvial or aquatic environment [7]. Sediments work as adsorbent pads for elements which can remobilize in due course under changed physical and chemical conditions of the water bodies [8]. However, sediments also act as habitat and major source of nutrients for aquatic organisms [9]. Recent examinations of river beds put more emphasis on the presence of trace elements in sediments because of their persistent, non-degradable nature and potential to enter the food chain. Elements entering the river system become bound to particulate matter, which after settling down become part of the sediments [10]. Though, elements such as Fe, $\mathrm{Zn}$ and $\mathrm{Cu}$ are required for the normal functions of the body, at concentrations higher than the required value they can be detrimental to the physiology and health of the living organisms. On the other hand, elements like $\mathrm{Cd}$ and $\mathrm{Pb}$ are toxic even at minute concentrations [5] [11]-[14]. Regular environmental monitoring and assessment of aquatic systems for the presence of elements is indispensable to examine possible impacts of developmental projects on their sediment environment. Since sediment environment directly influences the physicochemical and ecological dynamics of aquatic resources, a deteriorated sediment quality may severely impact the supports that sustain aquatic life and the surrounding ecosystem, which also includes human beings, dependent on it [15].

The Subarnarekha river basin, having catchment area of more than $19,200 \mathrm{~km}^{2}$ and providing about $0.4 \%$ of the country's total surface water resources [16], is one of the most important inter-state river basins of India. The river rises on the eastern slopes of the Chottanagpur plateau in Ranchi district (Jharkhand state) and flows through three states namely Jharkhand, West Bengal and Odisha before draining into the Bay of Bengal towards the eastern coast. The river predominantly flows through tribal belt and is extensively used for domestic and industrial purposes. It is the main receiving body of wastes from populated and industrialized regions like Ranchi, Adityapur, Jamshedpur and Ghatsila. Effluents of heavy and small scale industries located along the basin and the domestic and municipal wastes of the rural and urban areas are discharged into the river. Conventional water treatment plants are limited and inadequate which put additional stress on the ecology of the river. Owing to the rich occurrence of major mineral resources the basin has significant presence of mining and mineral processing units. Based on above mentioned information and the relatively new occurrence of two activities, that is, large scale quarrying of the river bed for construction materials (minor minerals) and encroachment, examination of the river basin becomes essential for ecological reasons. In this study geochemical distribution, enrichment and ecological risk of six elements were investigated. Eco-toxicological potential of $\mathrm{Cd}$ and other elements were described in terms of both threshold effect concentration (TEC) and probable effect concentration (PEC) of the sediment quality guidelines (SQGs) as well as ecological risk indices computed. The objectives of our investigation were: to determine spatial and temporal distribution patterns of six element concentrations in surface sediments of the Subarnarekha river in the Indian state of Jharkhand, where the river shows maximum presence; to assess control of anthropogenic activities on sediment contamination of elements; and to find out potential eco- 
logical risks to the benthic biota and other freshwater organisms associated with element concentrations. Additionally, since the National River Water Quality Monitoring Network in India mainly involves studying water quality, this study was a step in the direction to acquaint the public and the policy makers about sediment quality of the river to develop management strategies needed to remediate and control river bed contamination.

\section{Materials and Methods}

\subsection{Study Area}

The study area, located between latitudes $22^{\circ} 13^{\prime} 14 " \mathrm{~N}$ and $23^{\circ} 27^{\prime} 00^{\prime \prime} \mathrm{N}$; longitudes $85^{\circ} 11^{\prime} 00^{\prime \prime} \mathrm{E}$ and $86^{\circ} 42^{\prime} 50^{\prime \prime} \mathrm{E}$, consisted of three districts namely Ranchi, Saraikela Kharswan and Purba Singhbhum of the Jharkhand state, India. Subarnarekha river flows through these three districts before entering the Indian state of West Bengal near Gopiballabhpur in the West Medinipore district (Figure 1). The river during its course passes Ranchi uplands, Bhagmundi hills (Ayodhya pahar), Dalma and Dhanjori ranges. Its bed belongs to the hard rock of the PreCambrian or Archaean formations comprising mainly quartzites, granites, gneiss, dolomites, mica-schists, phyllites [17] and Dhanjori groups of volcanic rocks. Kharkai river, most important tributary of the river Subarnarekha, passes through one of the most important industrialized belts of Asia (Adityapur industrial area) and joins it near Sonari towards north-western periphery of the steel city Jamshedpur. In addition, Kanchi, Karkari, Garra, Gurma and Sankh are other significant tributaries that make the river basin. Downstream of the Jamshedpur city Garra, Gurma and Sankh rivers pass through key mining belts and join the river Subarnarekha at different places. Many heavy mining and processing belts, industrial conglomerates and populated areas are located along the basin which make river Subarnarekha as the main receiving body of industrial discharges, mine drainages, partially treated or untreated domestic wastes etc.

\subsection{Sediment Sampling}

Sediment samples were collected from seventeen selected locations along the Subarnarekha river (Figure 1) during May, 2011 (pre-monsoon) and November, 2011 (post-monsoon) periods. Sampling sites were selected based on surveys, that is, areas having high anthropogenic activities and areas relatively free of anthropogenic influences, and accessibility. Surface sediment samples (3 grabs per sample) were taken at a depth of about $5 \mathrm{~cm}$

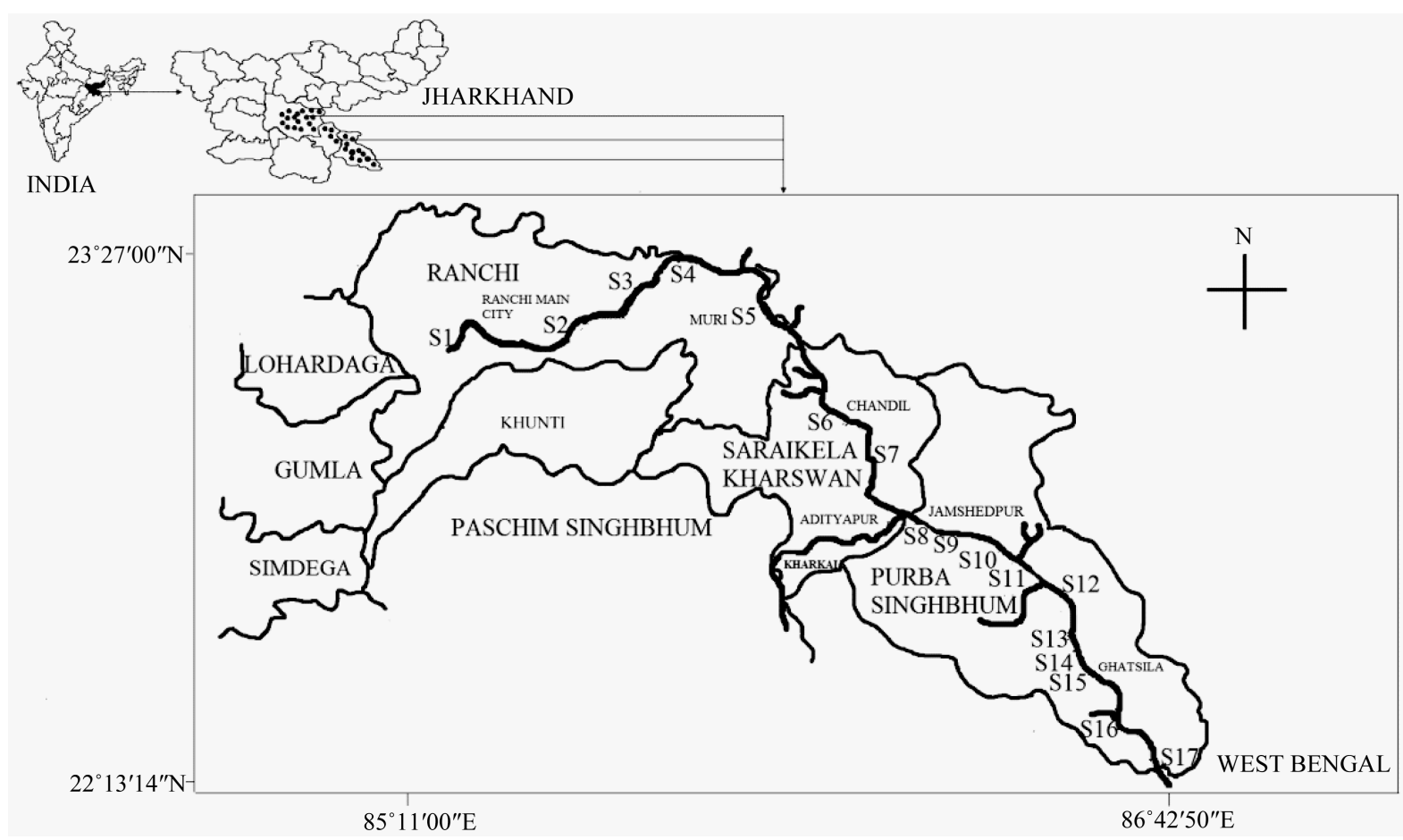

Figure 1. Study area and the sampling locations; black spots represent study area; capital "S" letter indicates sampling site. 
and immediately transferred into pre-cleaned polythene bags [18]. The collected samples were oven dried at $40^{\circ} \mathrm{C}$ for 48 hours; passed through a $1 \mathrm{~mm}$ plastic sieve to remove plant parts, debris and gravel-sized materials; and then sieved through a nylon sieve (aperture $125 \mu \mathrm{m}$ ). Use of fractions $<125 \mu \mathrm{m}$ for characterization of the bed sediments has also been reported earlier [3] [15]. The lower particle size sediment fractions were ground using mortar and pestle for homogenization and prepared for further analysis of physicochemical properties and concentration of six elements [19]. All necessary precautions and care were taken during drying, sieving, grinding and storage of sediment samples to avoid any kind of contamination.

\subsection{Physicochemical and Statistical Analyses}

The $\mathrm{pH}$ of the sediment samples was measured using a digital $\mathrm{pH}$ meter (pHTestr 30, Eutech instruments, Oaklon) in 1:2.5 sediment to water ratio. The suspension was allowed to stand overnight prior to $\mathrm{pH}$ measurement [3]. Electrical conductivity (EC) was determined using Systronics Conductivity Meter (Model 361) in sediment saturation extracts as described by [20]. Organic Carbon (OC) was measured by partial oxidation method as outlined by [21]. Widely used $\mathrm{HNO}_{3}+\mathrm{HClO}_{4}$ acid digestion procedure for total element analysis in sediment samples and as described by [22] was carried out. Briefly 1 gm of sample was digested on hot plate with acid mixture containing $10 \mathrm{ml}$ of concentrated $\mathrm{HNO}_{3}$ and $5 \mathrm{ml} 70 \% \mathrm{HClO}_{4}$. After cooling, the mixture was boiled with $20 \mathrm{ml}$ distilled water to release any fumes. The digested samples were filtered through Whatman No. 42 filters and made up to $25 \mathrm{ml}$ by adding distilled water in a volumetric flask. Concentrations of six elements, namely, Fe, $\mathrm{Zn}, \mathrm{Cu}, \mathrm{Pb}$, Cd and $\mathrm{Mn}$ were determined with Atomic Absorption Spectrophotometer (AAS: Varian AA50) at wavelengths $(\mathrm{nm})-\mathrm{Fe}=248.3, \mathrm{Zn}=213.9, \mathrm{Cu}=324.8, \mathrm{~Pb}=217, \mathrm{Cd}=228.8, \mathrm{Mn}=279.5$. Before running sample analysis, the AAS was subjected to calibration and standardization using appropriate standards. The basis of element quantification was calibration curves of standard solution of elements (Fe: HC001722, Zn: HC117124, Cu: HC114735, Pb: HC125468, Cd: HC123670, Mn: HC241921) purchased from Merck (KGaA), Germany. To check the accuracy of the data, calibration was verified by analyzing a midpoint calibration standard and a calibration blank with each batch of samples run. Reagent blank, prepared to assess presence of analytes or interference, was found to be devoid of any analytes. The analytical precision was also verified by running one replicate and one blank spike sample after each batch of sample [7]. The accuracy of the procedure was also checked running five replicates of the standard solution of each element (expressed as mean \pm standard deviation)—Fe: $0.998 \pm 0.053$, Zn: $0.55 \pm 0.029$, Cu: $0.126 \pm 0.014$, Pb: $0.22 \pm 0.021$, Cd: $0.049 \pm 0.0045$, Mn: $0.254 \pm 0.027$. The glassware were washed with $14 \% \mathrm{HNO}_{3}$ and rinsed thoroughly with Milli-Q quality water prior to use. The Milli-Q quality water was used throughout the experiments. All the chemicals and reagents used were of analytical grade purchased from Sigma-Aldrich (USA) and Merck (Germany and India). The raw data were subjected to basic statistical analysis to identify some descriptive statistical factors. Interrelationships between variables were determined by correlation analysis applying Pearson correlation coefficient.

\subsection{Calculation of Enrichment Factors and SQGs}

In the present study six indices, namely, contamination factor (CF), contamination degree (CD), pollution load index (PLI), enrichment factor (EF), geo-accumulation index (Igeo) and potential ecological risk index (PERI) were prepared and evaluated stepwise to determine degree of anthropogenic influence on the sediment quality. An integrated index is a collection of single indices determined separately and then combined to designate the overall quality of the sediment. Three integrated indices, namely, PLI, CD and PERI were used in this study. Methods of calculation and classification criteria of studied indices with references are presented in Table 1. CF, PLI and CD calculations involve comparing concentration of elements with their geochemical background reference value and then computing the indices. While CF is calculated for individual elements, CD and PLI provide overall information about the sediment contamination of study sites. Similar to CF, Igeo [27] is also computed for individual elements which supply valuable knowledge about the degree and extent of element load in the sediments. EF, as introduced by [25], is used to assess the degree of anthropogenic influence on element load in the sediments, and also to differentiate between elements originating from the natural or anthropogenic activities [9]. PERI, originally developed by [23], provides a mean to quantitatively evaluate ecological risk posed by multiple element pollutions in the bed sediments of aquatic systems [30]. It takes into account concentration of elements, their potential ecological risk factors (PERF), and the sedimentological toxic response factors (TRF). TRF assigned to elements used in the calculation of PERI are: $\mathrm{Cu}=\mathrm{Pb}=5$; $\mathrm{Cd}=30 ; \mathrm{Zn}=1$ [29]. Due to ab- 
Table 1. Sediment quality indices and their classification systems.

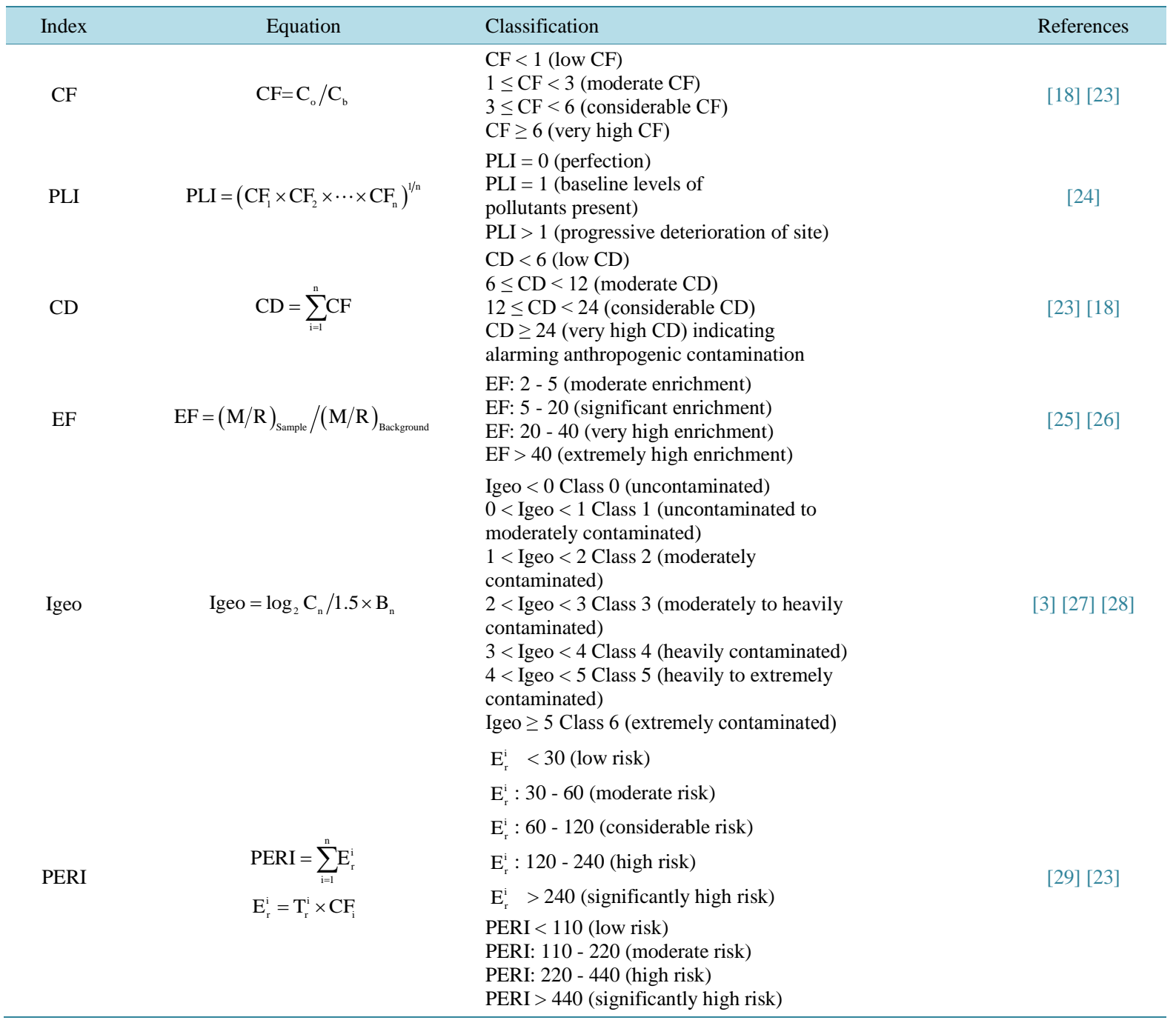

$\mathrm{CF}=$ Contamination Factor; PLI = Pollution Load Index; CD = Contamination Degree; EF = Enrichment Factor; Igeo = Geo-Accumulation Index; PERI = Potential Ecological Risk Index; Co = Observed Element Concentration; $\mathrm{C}_{\mathrm{b}}=$ Background Concentration of the Element; $\mathrm{M}=\mathrm{Element}$; $\mathrm{R}=$ Reference Element; $\mathrm{B}_{\mathrm{n}}=$ Background Concentration; $\mathrm{E}_{\mathrm{r}}^{\mathrm{i}}=$ Monomial Ecological Risk Index; $\mathrm{T}_{\mathrm{i}}^{\mathrm{r}}=$ Toxic Response Factor.

sence of any background concentration of elements from the studied area, average shale standards of trace elements described by [31] were taken as geochemical reference values in the present study. Fe was employed as normalization element to calculate EF values due to its abundance and controlling influence on the distribution of other trace elements [32] [33]. Based on positive correlations between sediment chemistry and sediment toxicity, [34] explained consensus-based sediment quality guidelines (SQGs) for classifying sediments as toxic and not-toxic. According to authors, SQGs are important tools for identifying contaminated sediment hotspots and also for assessing possible effects of contaminated sediments on benthic organisms. Threshold effect concentration (TEC) and probable effect concentration (PEC) are commonly employed for sediment contamination investigations with respect to elements [1] [35] as these guidelines provide predictive ability of adverse biological effects to the sediment dwelling fauna and other aquatic organisms [35]. TEC is defined as the concentration below which adverse effects are unlikely to be observed whereas PEC denotes concentration above which adverse effects are frequently expected to occur [34]. Another tool developed to study sediment toxicity is the mean sediment quality guideline quotients (mSQGQs). In the present study mSQGQs were derived following [36]. The quotients were, however, adjusted and derived from four analytes: $\mathrm{Zn}, \mathrm{Cu}, \mathrm{Pb}$ and $\mathrm{Cd}$. The methodology employed to investigate Subarnarekha river bed sediments is schematically represented in Figure 2. 


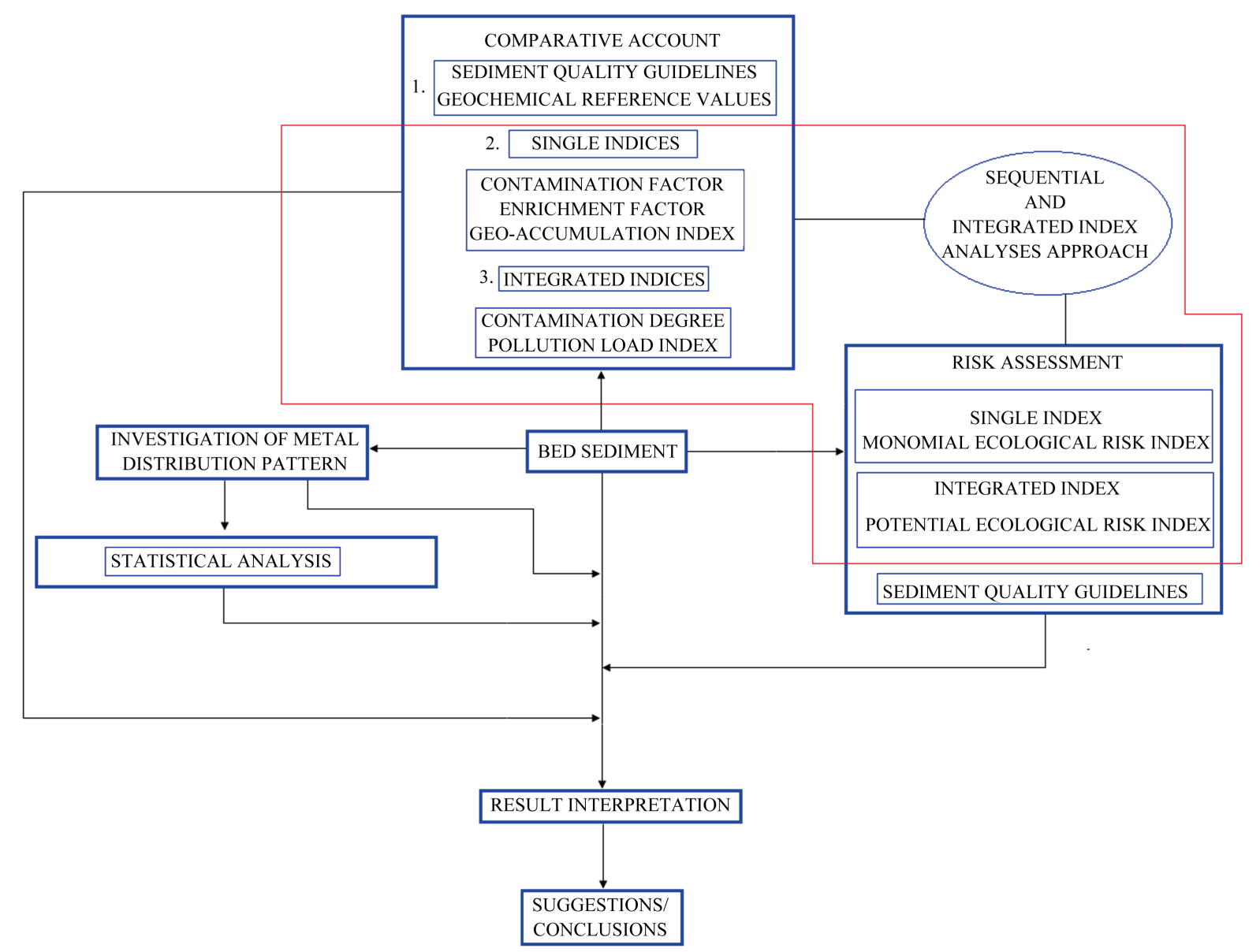

Figure 2. A schematic representation of methodology employed to characterize Subarnarekha bed sediments.

\section{Results and Discussion}

\subsection{Determination of $\mathrm{pH}, \mathrm{EC}$ and $\mathrm{OC}$}

The pH, EC and OC (\%) values obtained in the sediments of the river Subarnarekha during pre-monsoon study are displayed in Table 2; a summary of post-monsoon data of these measured parameters is also given in Table 3. The $\mathrm{pH}$ values ranged from 5.76 to 6.83 and 5.91 to 6.81 during pre-monsoon and post-monsoon periods respectively indicating slightly acidic nature of the sediments. This might have resulted from the formations of humic acid substances as well as discharge of acidic industrial, mining and domestic wastes into the river. EC of the sediment implies ability of the sediment to conduct electric current [37]. Lowest EC value was obtained at S1, which is a comparatively non-polluted site, while highest EC was recorded at S14 during both periods of study. Post-monsoon sediments had higher EC level $(0.153-1.147 \mathrm{~ms} / \mathrm{cm})$ than pre-monsoon sediments. OC values ranged from $2.97 \%$ to $5.34 \%$ during pre-monsoon and showed almost similar pattern in the second study period. Significantly higher values of OC were observed at S9, S14 and S15. In addition to adsorption and other related processes, elements are also incorporated into the sediment by organic complexation. Organic materials from river water and decomposed matter get enriched into the sediment [38]. However, smaller fractions of sediments display more efficient relationship with OC as compared to larger fractions.

\subsection{Element Concentrations and SQGs}

Concentrations of six studied elements recorded in collected surface sediments (of pre-monsoon season) from the Subarnarekha river are displayed in Table 2; a summary of post-monsoon data of the elements is also given in Table 3. Elements displayed wide variations in their distribution suggesting control of anthropogenic activi- 
Table 2. Recorded values of $\mathrm{pH}$, EC and OC and distribution of six measured elements in sediments of the Subarnarekha river, India.

\begin{tabular}{|c|c|c|c|c|c|c|c|c|c|}
\hline \multirow{2}{*}{$\begin{array}{l}\text { Sampling } \\
\text { locations }\end{array}$} & \multicolumn{9}{|c|}{ Physicochemical parameters and elements } \\
\hline & $\mathrm{pH}$ & $\begin{array}{c}\mathrm{EC} \\
(\mathrm{mS} / \mathrm{cm})\end{array}$ & $\begin{array}{l}\text { OC } \\
(\%)\end{array}$ & $\begin{array}{c}\mathrm{Fe} \\
(\mathrm{mg} / \mathrm{kg})\end{array}$ & $\begin{array}{c}\mathrm{Zn} \\
(\mathrm{mg} / \mathrm{kg})\end{array}$ & $\begin{array}{c}\mathrm{Cu} \\
(\mathrm{mg} / \mathrm{kg})\end{array}$ & $\begin{array}{c}\mathrm{Pb} \\
\text { (mg/kg) }\end{array}$ & $\begin{array}{c}\mathrm{Cd} \\
(\mathrm{mg} / \mathrm{kg})\end{array}$ & $\begin{array}{c}\mathrm{Mn} \\
(\mathrm{mg} / \mathrm{kg})\end{array}$ \\
\hline $\mathrm{S} 1$ & 6.83 & 0.142 & 3.32 & 12631.00 & 30.11 & 11.71 & 11.70 & 0.60 & 450.35 \\
\hline $\mathrm{S} 2$ & 6.41 & 0.407 & 4.76 & 30319.00 & 30.56 & 19.30 & 21.41 & 1.30 & 312.78 \\
\hline S3 & 6.76 & 0.315 & 3.85 & 27327.00 & 13.10 & 24.71 & 13.02 & 0.57 & 500.83 \\
\hline S4 & 6.83 & 0.378 & 2.97 & 28770.00 & 17.66 & 8.34 & 5.70 & 0.50 & 252.30 \\
\hline S5 & 6.20 & 0.432 & 4.69 & 30286.00 & 31.78 & 13.72 & 18.41 & 1.60 & 665.60 \\
\hline S6 & 6.43 & 0.526 & 3.85 & 36077.00 & 45.00 & 24.90 & 21.23 & 0.70 & 712.90 \\
\hline S7 & 6.47 & 0.683 & 3.46 & 30319.00 & 58.61 & 91.80 & 18.07 & 1.26 & 960.21 \\
\hline S8 & 6.30 & 0.812 & 4.39 & 40889.00 & 36.34 & 28.90 & 18.42 & 1.61 & 1945.58 \\
\hline S9 & 6.18 & 0.875 & 5.08 & 56736.00 & 60.74 & 40.75 & 22.20 & 1.68 & 2449.30 \\
\hline $\mathrm{S} 10$ & 6.75 & 0.831 & 3.27 & 36578.00 & 37.72 & 28.76 & 13.50 & 1.10 & 1032.36 \\
\hline S11 & 6.72 & 0.782 & 3.14 & 21814.00 & 31.50 & 28.37 & 8.01 & 0.70 & 574.80 \\
\hline $\mathrm{S} 12$ & 6.14 & 0.894 & 4.75 & 31910.00 & 37.22 & 28.20 & 13.81 & 1.34 & 1343.54 \\
\hline S13 & 6.25 & 0.647 & 4.39 & 20293.00 & 26.91 & 16.70 & 8.13 & 1.20 & 434.31 \\
\hline S14 & 5.76 & 1.128 & 5.34 & 125516.00 & 288.80 & 2121.70 & 40.10 & 3.08 & 706.81 \\
\hline S15 & 5.85 & 0.984 & 5.12 & 36786.00 & 68.50 & 94.70 & 24.68 & 2.30 & 586.24 \\
\hline S16 & 6.12 & 0.817 & 3.63 & 30586.00 & 28.37 & 42.23 & 11.40 & 1.41 & 446.30 \\
\hline $\mathrm{S} 17$ & 6.48 & 0.685 & 4.07 & 13237.00 & 9.20 & 2.00 & 4.80 & 1.24 & 468.71 \\
\hline Minimum & 5.76 & 0.142 & 2.97 & 12631.00 & 9.20 & 2.00 & 4.80 & 0.50 & 252.30 \\
\hline Maximum & 6.83 & 1.128 & 5.34 & 125516.00 & 288.80 & 2121.70 & 40.10 & 3.08 & 2449.30 \\
\hline Mean & 6.38 & 0.667 & 4.12 & 35886.71 & 50.13 & 154.49 & 16.14 & 1.30 & 814.20 \\
\hline Median & 6.41 & 0.685 & 4.07 & 30319.00 & 31.80 & 28.00 & 13.80 & 1.24 & 586.20 \\
\hline${ }^{\mathrm{a}} \mathrm{SD}$ & 0.33 & 0.264 & 0.76 & 25311.42 & 63.54 & 507.58 & 8.60 & 0.66 & 594.41 \\
\hline Skewness & -0.23 & -0.317 & 0.056 & 3.04 & 3.70 & 4.11 & 1.23 & 1.26 & 1.83 \\
\hline Kurtosis & -0.68 & -0.526 & -1.331 & 10.85 & 14.51 & 16.90 & 2.61 & 2.28 & 2.99 \\
\hline${ }^{\mathrm{b}} \mathrm{TEC}$ & - & - & - & - & 121.00 & 31.60 & 35.80 & 0.99 & - \\
\hline${ }^{\mathrm{b}} \mathrm{PEC}$ & - & - & - & - & 459.00 & 149.00 & 128.00 & 4.98 & - \\
\hline
\end{tabular}

${ }^{\mathrm{a}}$ Standard deviation; ${ }^{\mathrm{b}}$ Consensus based sediment quality guidelines (CSQGs).

Table 3. A synopsis of analyzed results of the Subarnarekha bed sediments in post-monsoon period.

\begin{tabular}{|c|c|c|c|c|c|c|c|c|}
\hline & \multicolumn{2}{|c|}{ Parameters, CD, PLI and PERI } & \multicolumn{2}{|c|}{$\mathrm{CF}$} & \multicolumn{2}{|c|}{$\mathrm{EF}$} & \multicolumn{2}{|c|}{ Igeo } \\
\hline & Min & Max & Min & Max & Min & Max & Min & Max \\
\hline $\mathrm{pH}$ & 5.83 & 6.87 & - & - & - & - & - & - \\
\hline EC & 0.153 & 1.147 & - & - & - & - & - & - \\
\hline OC & 2.92 & 5.47 & - & - & - & - & - & - \\
\hline $\mathrm{Fe}$ & 12,638 & 125,603 & 0.268 & 2.662 & - & - & -2.486 & +0.828 \\
\hline $\mathrm{Zn}$ & 8.73 & 302.96 & 0.092 & 3.189 & 0.248 & 1.206 & -4.029 & +1.088 \\
\hline $\mathrm{Cu}$ & 2.17 & 2184.63 & 0.048 & 48.550 & 0.182 & 19.320 & -4.959 & +5.017 \\
\hline $\mathrm{Pb}$ & 4.92 & 53.91 & 0.246 & 2.696 & 0.509 & 2.384 & -2.608 & +0.846 \\
\hline Cd & 0.54 & 4.79 & 1.8 & 15.967 & 3.096 & 10.757 & +0.263 & +3.412 \\
\hline $\mathrm{Mn}$ & 257.83 & 2478.53 & 0.385 & 2.916 & 0.359 & 2.665 & -2.306 & +0.959 \\
\hline CD & 3.512 & 74.02 & - & - & - & - & - & - \\
\hline PLI & 0.293 & 5.069 & - & - & - & - & - & - \\
\hline PERI & 60.44 & 738.43 & - & - & - & - & - & - \\
\hline
\end{tabular}

Values of $\mathrm{pH}$ in $\mathrm{pH}$ units; EC in mS/cm; OC in \%; elements in mg/kg; Min = Minimum; Max = Maximum. 
ties on sediment chemistry. Although similar spatial variability of elements was recorded for the Subarnarekha river sediments in both pre-monsoon and post-monsoon periods, the latter displayed higher concentration load than the former. This could be due to more runoffs from industrial, mining, urban and agricultural areas during rainy season. Elements released into aquatic environments become bound to the particulate matters which in due course settle down and become part of the sediments [10]. Overall concentration of trace elements followed the order: $\mathrm{Fe}>\mathrm{Mn}>\mathrm{Cu}>\mathrm{Zn}>\mathrm{Pb}>\mathrm{Cd}$. The sampling site $\mathrm{S} 14$ recorded highest concentration of $\mathrm{Fe}, \mathrm{Zn}, \mathrm{Cu}, \mathrm{Pb}$ and Cd while S9 showed maximum Mn value. Four sampling stations S8, S9, S14 and S15 regularly displayed more element concentrations compared to others. S8 and S9 are located in the Jamshedpur city, a highly populated and industrialized belt of Jharkhand. Moreover, river Kharkai, which carries industrial and domestic wastes from the Adityapur industrial area, one of the largest in Asia, joins the river Subarnarekha near S8. The river at S14, located nearby a copper factory site and upstream of Ghatsila town, and S15, situated downstream of Ghatsila, is a major industrial and domestic discharges receiving body. Sampling sites located nearby industrial, mining and urban areas either exceeded TEC with respect to $\mathrm{Cd}, \mathrm{Pb}, \mathrm{Cu}$ and $\mathrm{Zn}$ or closely approached the benchmark, while for PEC, concentration of elements at sampling sites S14 and S15 was relatively very high. Analyzed appraisal with SQGs (TECs and PECs) and the results of temporal study indicated adverse eco-toxic effects from long term exposure of elements which was more alarming for Cd. Elements also exceeded their average shale standard concentrations in sampling sites characterized by high anthropogenic activities. More pronounced results were obtained at S7, S8, S9, S14 and S15 where elements surpassed their geochemical background values as high as forty seven times indicating high enrichment of sediments with elements. Accumulation of elements in bed sediments of the river Subarnarekha as compared to some other river sediments around the world, even though each area has its own geochemical characteristics, indicate higher load for $\mathrm{Fe}, \mathrm{Cu}$ and Mn and substantial enrichment for Cd (Table 4). The spatial and temporal investigation revealed Cd as the biggest contaminant and chief cause of concern. Cd concentration was noted above its geochemical background value throughout the studied area in both study periods; however, its concentration was significantly higher at sites characterized by dominant anthropogenic activities. Contamination of sediments of freshwater systems with $\mathrm{Cd}$ is increasingly becoming a major problem in developing countries worldwide. Some cases include: Gomti river (India) 0.70 to $7.90 \mathrm{mg} / \mathrm{kg}$ [40]; Achankovil river (India) 3.67 to $11.43 \mathrm{mg} / \mathrm{kg}$ [7]; Hindon river (India) 1.30 to $3.28 \mathrm{mg} / \mathrm{kg}$ [10]; Buriganga (Bangladesh) 3.5 to $7.8 \mathrm{mg} / \mathrm{kg}$ and 4.1 to $9.5 \mathrm{mg} / \mathrm{kg}$ in summer and winter seasons respectively [43], Lianshan and Wuli rivers (China) 25.53 to $98.78 \mathrm{mg} / \mathrm{kg}$ and 8.04 to 17.75 $\mathrm{mg} / \mathrm{kg}$ respectively [30]. Not only rivers, Cd contamination are also being recorded for the wetland systems. For examples, Bangalore urban lakes (India) recorded 4.68 to $14.25 \mathrm{mg} / \mathrm{kg}$ Cd [44] and Vembanad wetland system in Kerala (India) 0.26 to $0.73 \mathrm{mg} / \mathrm{kg}$ [1]. Results of only one season (pre-monsoon) are displayed in tables and figures, unless otherwise mentioned.

Table 4. Comparison of mean element concentrations recorded in present investigation with some other studies.

\begin{tabular}{|c|c|c|c|c|c|c|}
\hline \multirow{2}{*}{ Rivers } & \multicolumn{6}{|c|}{ Parameters } \\
\hline & $\mathrm{Fe}$ & $\mathrm{Cu}$ & $\mathrm{Zn}$ & $\mathrm{Pb}$ & $\mathrm{Cd}$ & $\mathrm{Mn}$ \\
\hline Yarmouk $^{\mathrm{a}}$ & 25883.22 & - & 172.61 & 67.20 & 8.48 & 594.50 \\
\hline Gomti $^{\mathrm{b}}$ & 6735.77 & 10.705 & 42.83 & 51.04 & 2.53 & 220.33 \\
\hline Achankovil $^{\mathrm{c}}$ & 11858 & 224 & 415 & 72 & 6 & 699 \\
\hline Orogodo $^{\mathrm{d}}$ & 24.60 & 2.50 & 1.26 & 4.39 & 0.49 & 1.60 \\
\hline Ganga $^{e}$ & 5816.50 & 12.82 & 49.02 & 2.50 & 3.08 & 148.50 \\
\hline Hindon $^{\mathrm{f}}$ & 233.72 & 59.33 & 58.29 & 41.20 & 2.29 & 150.88 \\
\hline Dikrong $^{\mathrm{g}}$ & 1.76 & 190.10 & 26.40 & 39.10 & - & 548.80 \\
\hline Euphrates $^{\mathrm{h}}$ & 661.70 & 14.14 & 67.66 & 0.59 & 11.22 & 37.70 \\
\hline Shale standard ${ }^{\mathrm{i}}$ & 47200 & 45 & 95 & 20 & 0.3 & 850 \\
\hline Present study & 35886.71 & 154.49 & 50.13 & 16.14 & 1.30 & 814.20 \\
\hline
\end{tabular}

${ }^{\mathrm{a}}[39] ;{ }^{\mathrm{b}}[40] ;{ }^{\mathrm{c}}[\mathrm{7}] ;{ }^{\mathrm{d}}[37] ;{ }^{\mathrm{e}}[41] ;{ }^{\mathrm{f}}[10] ;{ }^{\mathrm{g}}[33] ;{ }^{\mathrm{h}}[42] ;{ }^{\mathrm{i}}[31] ;$ All values in mg/kg. 


\subsection{Sequential and Integrated Index Analyses Approach}

CF is used to illustrate the contamination of particular toxic substance at a given site [1]. The characteristic terminologies of CF and its calculated values in the sediment samples from the Subarnarekha river are given in Table 1 and Table 5 respectively. S14 displayed moderate contamination for Fe; considerable contamination for $\mathrm{Zn}$; moderate contamination for $\mathrm{Pb}$; and very high contamination for $\mathrm{Cd}$ and $\mathrm{Cu}$ in both pre-monsoon (10.27 and 47.15) and post-monsoon periods (15.97 and 48.55) indicating serious anthropogenic contribution to the contamination load of sediments at this site. Meanwhile contaminations of sediments, with reference to one or more elements, were also reported from S2, S6, S7, S8, S9, S12 and S15. Of the two study periods, the sediment was more contaminated in post-monsoon period. Trace element $\mathrm{Cd}$ revealed as the most severe component causing moderate to very high contamination of the sediments in both periods of study. Similar pattern was noted for contamination degree (CD) (Figure 3(a)), where sampling sites having dominant anthropogenic activities displayed high CD. This demonstrates regular monitoring of the sediments for the presence of trace elements especially cadmium is required. In geochemical investigations, PLI is used as a resourceful tool to measure and compare sediment contamination. Analyzed sediments at S7 (1.231), S8 (1.158) and S9 (1.524) towards upstream segment, and S14 (4.337) and S15 (1.407) towards downstream region displayed higher PLI values and progressive deterioration in quality (Figure 3(a)). S14 recorded highest PLI closely followed by S15. Comparatively higher PLIs (0.293 - 5.069) were noticed in post-monsoon study (Table 3), which indicated more enrichment of metals. Higher PLI values in sediments demonstrated substantial anthropogenic impacts on the sediment quality whereas lower PLI values pointed to no considerable anthropogenic activities. This investigation strengthened employment of CD and PLI as effective instruments for assessing the environmental geochemistry of sediments and could be used individually or in combination as they closely complemented each other. Moreover, they easily convey information to the public and policy makers to ascertain the contamination load of the sediments to take necessary remedial measures. To measure degree and extent of element contamination in freshwater resources EF and Igeo can also be used as reference systems [10]. Geo-accumulation index consists of a seven grade sediment quality classification scheme varying from uncontaminated to extremely contaminated

Table 5. Contamination factor of six studied elements in bed sediments.

\begin{tabular}{|c|c|c|c|c|c|c|}
\hline \multirow{2}{*}{$\begin{array}{l}\text { Sampling } \\
\text { locations }\end{array}$} & \multicolumn{6}{|c|}{ Contamination factor } \\
\hline & $\mathrm{Fe}$ & $\mathrm{Zn}$ & $\mathrm{Cu}$ & $\mathrm{Pb}$ & $\mathrm{Cd}$ & $\mathrm{Mn}$ \\
\hline $\mathrm{S} 1$ & 0.268 & 0.317 & 0.260 & 0.585 & 2.0 & 0.506 \\
\hline $\mathrm{S} 2$ & 0.642 & 0.322 & 0.429 & 1.071 & 4.333 & 0.368 \\
\hline S3 & 0.579 & 0.138 & 0.549 & 0.651 & 1.9 & 0.589 \\
\hline $\mathrm{S} 4$ & 0.610 & 0.186 & 0.185 & 0.285 & 1.667 & 0.297 \\
\hline S5 & 0.642 & 0.335 & 0.305 & 0.921 & 5.333 & 0.783 \\
\hline S6 & 0.764 & 0.474 & 0.533 & 1.062 & 2.333 & 0.839 \\
\hline S7 & 0.642 & 0.617 & 2.04 & 0.904 & 4.2 & 1.130 \\
\hline S8 & 0.866 & 0.383 & 0.642 & 0.921 & 5.637 & 2.289 \\
\hline S9 & 1.20 & 0.639 & 0.906 & 1.11 & 5.6 & 2.882 \\
\hline $\mathrm{S} 10$ & 0.775 & 0.397 & 0.639 & 0.675 & 3.667 & 1.215 \\
\hline $\mathrm{S} 11$ & 0.462 & 0.332 & 0.630 & 0.401 & 2.333 & 0.676 \\
\hline $\mathrm{S} 12$ & 0.676 & 0.392 & 0.627 & 0.691 & 4.467 & 1.581 \\
\hline $\mathrm{S} 13$ & 0.430 & 0.283 & 0.371 & 0.407 & 4.0 & 0.511 \\
\hline $\mathrm{S} 14$ & 2.659 & 3.04 & 47.147 & 2.008 & 10.267 & 0.832 \\
\hline $\mathrm{S} 15$ & 0.779 & 0.721 & 2.104 & 1.234 & 7.667 & 0.690 \\
\hline $\mathrm{S} 16$ & 0.648 & 0.299 & 0.938 & 0.570 & 4.70 & 0.525 \\
\hline $\mathrm{S} 17$ & 0.280 & 0.097 & 0.045 & 0.240 & 4.133 & 0.551 \\
\hline
\end{tabular}



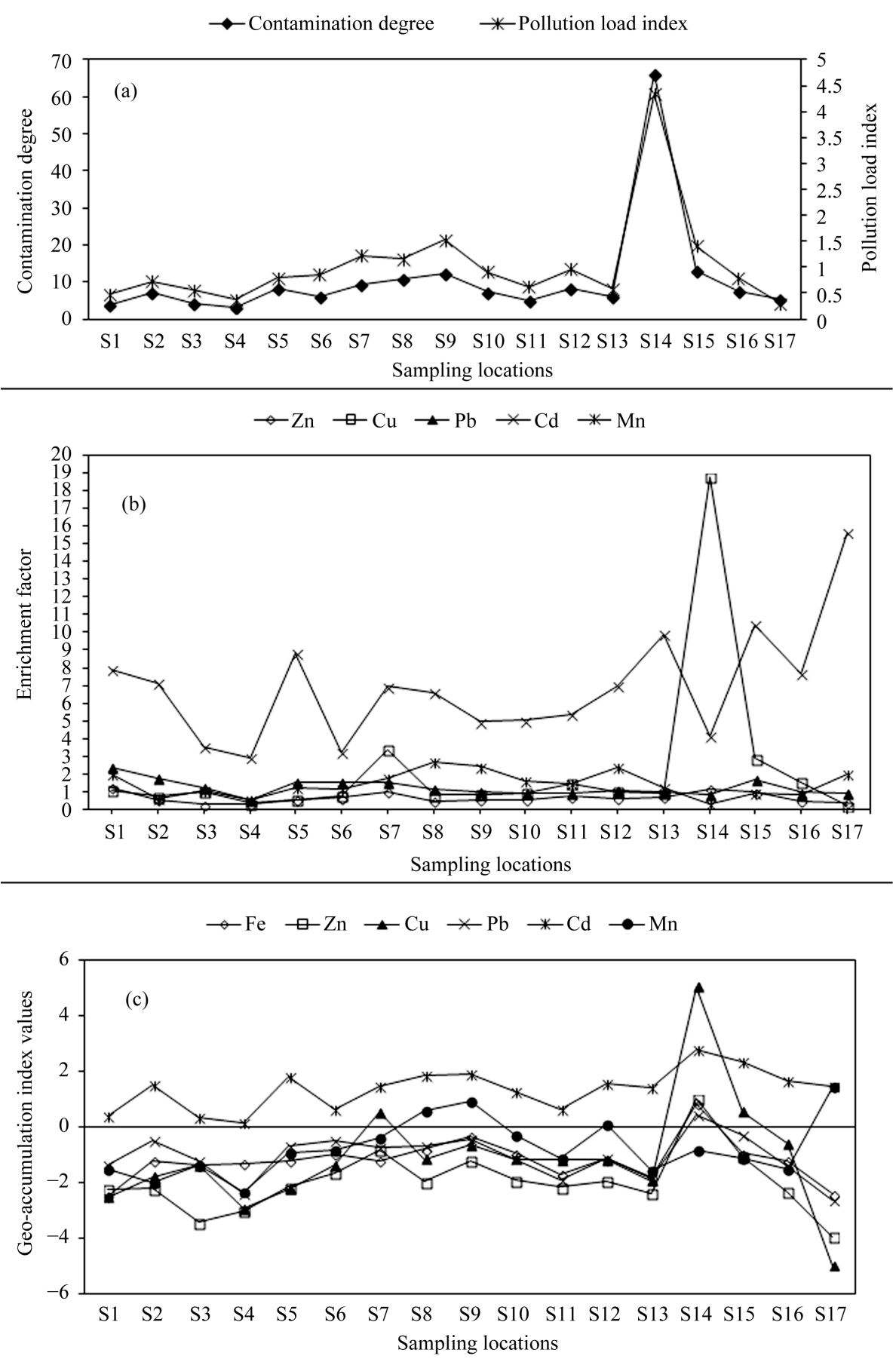

Figure 3. Contamination degrees and pollution load indices of sediments at different sites (a), enrichment factor values (b) and sediment geo-accumulation indices (c) of trace elements in Subarnarekha river bed sediments.

categories. According to [40] Class 6 indicates 64 fold enrichment above the geochemical background value. The EF and Igeo values calculated for studied elements in all sediment samples and variations obtained (premonsoon data) are graphically presented in Figure 3(b) and Figure 3(c) respectively. A brief post-monsoon summary of these indices is also given in Table 3. The EF and Igeo exhibited similar spatial variations in both study periods; however, temporally post-monsoon period was more contaminated. Analysis of results displayed sediment samples collected from urban-industrial areas enriched with $\mathrm{Cu}$ and Mn. Sites S7 and S15 showed 
moderate enrichment for $\mathrm{Cu}$ while S14 demonstrated significantly high enrichment for the element. Moderate enrichment for Mn was noted at S8, S9 and S12. Sediments of Subarnarekha were found to be uniformly enriched with Cd which varied from moderate to significant enrichment. However, with some exceptions, sampling sites dominated by industrial, mining and other anthropogenic activities presented elevated Cd enrichment. Analyzed results showed sediment at S14 was moderately contaminated with Fe and $\mathrm{Zn}$. The Igeo of $\mathrm{Cu}$ varied from uncontaminated to extremely contaminated, and the latter was recorded at S14 (+5.045). Sediments of S7 and S15 suggested uncontaminated to moderate contamination of $\mathrm{Cu}$. For Pb only S14 exhibited some degree of contamination. Presence of Cd again demonstrated severe contamination of the Subarnarekha sediments where its Igeo ranged from +0.152 (S4) to +2.775 (S14).

The indices mentioned above deal with anthropogenic input and estimate contamination not toxicity. While contamination is related with anthropogenic input, pollution describes toxicity. As lucidly explained by [45], the contamination is said to happen when a substance is present where it should not occur in general or at concentrations above the background level. On the other hand, pollution is that contamination that can cause adverse biological effects to the natural biotic communities. Thus, in addition to quantify accumulation of trace elements in sediments and apportion anthropogenic impacts, a tool is needed to express potential effects of presence of multiple elements in the sediments, that is contamination situation, on ecological risks or harm to the local ecosystem [29] [30]. Potential ecological risk index (PERI) and also SQGs can be applied in ecological risk assessments of trace element pollutants in soils and sediments. However, SQGs (as described earlier) are elementspecific and do not take into account multiple element mixtures which are normally expected in the environmental studies. These are used for initial determination to assess whether or not contaminants of potential concern could cause any harm to the receptors of potential concern [45]. To overcome this gap mSQGQs have been developed; which involve chemical mixtures normalized to their appropriate SQGs to determine biological effects. [36] expressed a broad range of toxicity incidence, between low $(<0.1)$ and high $(>2.3)$, based on their mSQGQ method. We recalibrated their toxicity quotients based on average (\%) survival of amphipods and developed a new modified terminology on mSQGQ classification system, which can be expressed as: $<0.1$ (very low incidence of toxicity), $0.1-0.25$ (low incidence of toxicity), 0.25 - 1.0 (moderate incidence of toxicity), 1.0 - 2.3 (high incidence of toxicity) and >2.3 (extremely high incidence of toxicity). Sampling site S14 displayed adjusted mSQGQ very close to high incidence of toxicity (0.813) during post-monsoon season which was almost 2.3 times than the pre-monsoon value (0.359). According to [35] SQGs should be applied either as a screening approach or a weight-of-evidence procedure for the risks associated with the contaminated sediments. An integrated index system like PERI provides more valuable insights into eco-toxicological effects of elements polluting bed sediments. Except five non-polluted sites, the PERI of studied sediments varied from moderate risk to significantly high risk (116.98 - 556.83) during pre-monsoon period, indicating that sediments in the Subarnarekha river were exceedingly polluted by elements (Figure 4), especially present in discharges of industrial and urban wastes. The river showed similar spatial distribution of ecological risk in post-monsoon period; however, corresponding PERI recorded was higher which varied from 128.76 - 738.43. Cd displayed highest monomial potential ecological risk, which varied from 50.01 to 308.01 (pre-monsoon) and 54.00 to 479.01 (post-monsoon) followed by Cu (235.74 - 242.75) at S14. Analyzed results always showed pronounced Cd con-

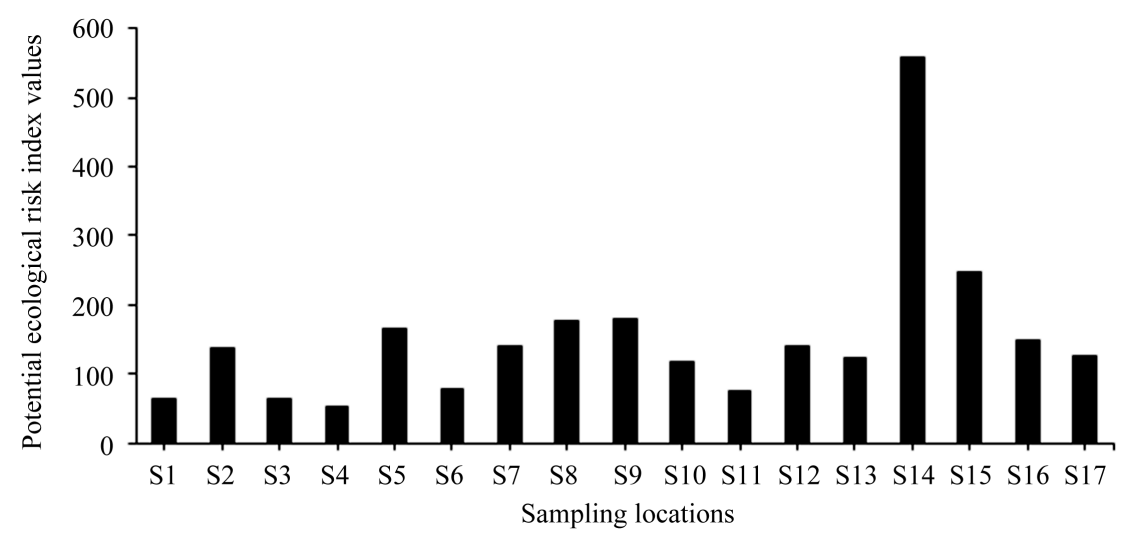

Figure 4. Potential ecological risk indices determined in Subarnarekha river sediments. 
tribution in PERI of bed sediments because of its higher toxicity response factor as compared to other elements and excessive enrichment. Authors like [29] [30] [46] in their studies on soils and sediments have also demonstrated enhanced role of $\mathrm{Cd}$ in causing ecological risks. Acute toxicity due to $\mathrm{Cd}$ in the Subarnarekha bed sediments would be expected at $64 \%$ of the sites. Assessment of distribution and degree of accumulation of Cd and other elements in bed sediments not only provide information on anthropogenic enrichment, but also potential ecological risks associated with their exposure. Enrichment of $\mathrm{Cd}$ and other elements in aquatic beds can affect entire range of biotic spectrum ranging from benthic biota to the organisms higher up the food chains due to their persistence, bio-accumulative and injurious properties. In aquatic ecosystems both abiotic and biotic components continuously interact with each other and presence of toxic elements beyond the restoring capacity can severely impact the ecological functioning of the aquatic systems in long term, which in short term may not be visible to us. Here, it should also be noted that, although, both PLI and PERI are based on CF values, the former does not take into account any sedimentological toxicity factor whereas the latter uses a toxicity factor for its computation. PLI portrays contamination situation and not ecological risk, and therefore, we suggest, the term PLI should be replaced with CLI (contamination load index). The clear-cut definitions of contamination and pollution also support this observation.

Correlation analyses are commonly employed to determine relationships between physicochemical components as well as identification of factors and sources of variables. Results of Pearson correlation analysis applied in the present investigation and the corresponding matrix generated are displayed in Table 6. Most of the elements showed strong correlation with OC at $P<0.05$ and $P<0.01$ suggesting presence of organic matter influenced elements' accumulation in the sediments. Impact of organic pollution load in causing enhanced element enrichment in bed sediments was also reported for the Hindon river in India [10]. Elements showing significantly high relationship in correlation analysis may indicate same origin and controlling factors [47]. Very strong correlation was noticed between Fe and most of the elements ( $\mathrm{Zn}, \mathrm{Cu}, \mathrm{Pb}$ and $\mathrm{Cd}$ ) at $P<0.01$ suggesting some common sources of elements in the Subarnarekha. In addition to industrial effluents and urban wastewater, possibly urban runoffs and atmospheric deposition were also contributing to the element pollution of the river. Moreover, as the river basin has rich occurrence of ores containing $\mathrm{Fe}, \mathrm{Zn}, \mathrm{Cu}$ and $\mathrm{Pb}$, their chemical weathering and leaching might also be contributing elements in the sediments. However, elevated concentrations and dominance of these elements at industrial hubs and predominantly urban regions like S7, S8, S9, S14 and S15 revealed that industrial and other anthropogenic activities were overwhelmingly responsible for the presence of these elements in the bed sediments. Similarly strong correlation was noted between $\mathrm{Zn}, \mathrm{Cu}, \mathrm{Pb}$ and $\mathrm{Cd}$ at $P<$ 0.01 demonstrating elements had a common source. Meanwhile, positive correlation was also noticed between $\mathrm{Cu}, \mathrm{Pb}$ and $\mathrm{Cd}(P<0.01)$. The common presence of $\mathrm{Cd}$ in correlation analysis indicated that the element had chiefly anthropogenic origin. Towards upper reaches application of mineral fertilizers and consequent agricultural runoff were principally responsible for its presence in river. [48] observed higher concentrations of Cd in upper reaches of Siahroud river from agricultural use of phosphorus, zinc and iron fertilizers. The element is used in electroplating, batteries, paints, pigments and in alloys with a range of other elements and also occurs in

Table 6. Pearson correlation analysis comprising physicochemical parameters and elements.

\begin{tabular}{|c|c|c|c|c|c|c|c|c|c|}
\hline & $\mathrm{pH}$ & EC & OC & $\mathrm{Fe}$ & $\mathrm{Zn}$ & $\mathrm{Cu}$ & $\mathrm{Pb}$ & $\mathrm{Cd}$ & $\mathrm{Mn}$ \\
\hline $\mathrm{pH}$ & 1 & $-0.688^{* *}$ & $-0.845^{* *}$ & $-0.602^{*}$ & $-0.588^{*}$ & $-0.507^{*}$ & $-0.676^{* *}$ & $-0.893^{* *}$ & -0.247 \\
\hline EC & & 1 & 0.453 & $0.528^{*}$ & $0.482^{*}$ & 0.395 & 0.405 & $0.709^{* *}$ & 0.462 \\
\hline OC & & & 1 & $0.549^{*}$ & $0.494^{*}$ & 0.424 & $0.693^{* *}$ & $0.791^{* *}$ & 0.354 \\
\hline $\mathrm{Fe}$ & & & & 1 & $0.950^{* *}$ & $0.919^{* *}$ & $0.855^{* *}$ & $0.778^{* *}$ & 0.270 \\
\hline $\mathrm{Zn}$ & & & & & 1 & $0.977^{* *}$ & $0.831^{* *}$ & $0.783^{* *}$ & 0.081 \\
\hline $\mathrm{Cu}$ & & & & & & 1 & $0.737^{* *}$ & $0.716^{* *}$ & -0.037 \\
\hline $\mathrm{Pb}$ & & & & & & & 1 & $0.785^{* *}$ & 0.270 \\
\hline $\mathrm{Cd}$ & & & & & & & & 1 & 0.268 \\
\hline Mn & & & & & & & & & 1 \\
\hline
\end{tabular}

${ }^{*}$ Correlation is significant at the 0.05 level (two tailed); ${ }^{* *}$ Correlation is significant at the 0.01 level (2-tailed). 
sulphide minerals containing $\mathrm{Zn}, \mathrm{Pb}$ and $\mathrm{Cu}$ [49]. Also overall concentration of $\mathrm{Cd}$ was reported to be four times its geochemical background. However, no significant relationship was observed for Mn with any other element, possibly because unlike other elements Mn had different sediment deposition features [10]. The Subarnarekha river from its origin to the border of Jharkhand (with West Bengal) receives effluents and discharges of big and small industrial conglomerates, populated urban areas and extensively mined regions. Additionally, open dumping of garbage beside river banks and washing of automobiles and vehicles in river water are making sediments of Subarnarekha increasingly contaminated.

Degradation of river bed sediment quality portrays river degradation as a whole because it is the outcome of river water pollution. The problem of river basin degradation is more pronounced in developing countries because expanding economic growth puts terrific pressure on the limited available natural resources. As per the assessment of the renowned economic consultancy the Centre for Economics and Business Research (CEBR) in World Economic League Table Report, the Indian economy, which presently holds $11^{\text {th }}$ position in the world, is growing very fast, and by 2028, it is expected to become the $3^{\text {rd }}$ largest economy after China and United States [50] overtaking Japan. Meanwhile, the population of India is also expected to surpass 1.45 billion. Thus, to satisfy the demand of the growing population along with the economic growth, massive industrialization, urbanization, changes in land use pattern and intensive agriculture are inevitable. All these activities, in turn, will affect river basins if complete attention is not given. The Subarnarekha basin will have more alarming situation because, according to the International Water Management Institute (IWMI, Colombo, Sri Lanka) research report, currently its population density (347 persons per $\mathrm{km}^{2}$ ) is already much ahead of the national average of all river basins (282 persons per $\mathrm{km}^{2}$ ), and in terms of some major river basins it lies only behind Sabarmati (521), Ganges (449) and Cauvery (389) [51]. The information obtained through this research communication, based on systematic investigation of the sediment quality, provides valuable insights for result-oriented environmental management of the industrial, urban, mining and mineral processing regions. Some immediate requirements on effective management policies and conservation strategies are needed to prevent the current contamination situation developing into pollution problems all through the river basin.

\section{Conclusion}

The bed sediments collected nearby industrial, urban and mining sites exceedingly displayed elevated concentration of elements, at times much above their background values, which markedly highlighted anthropogenic control on enrichment and geochemical distribution of trace elements in the Subarnarekha river. Although similar spatial variations in element contents were recorded in pre-monsoon and post-monsoon periods, the latter showed higher concentration load than the former. River sediment at S14 (Moubhandar) emerged as the most contaminated where highest $\mathrm{EF}$ for $\mathrm{Zn}$ and $\mathrm{Cu}$, maximum $\mathrm{CD}$ and PLI (CLI) values, and highest Igeo values for $\mathrm{Fe}, \mathrm{Zn}, \mathrm{Cu}, \mathrm{Pb}$ and $\mathrm{Cd}$ were recorded. The site was also most polluted as evident from mSQGQ and PERI measures. Based on ecological risk assessment methods (SQGs and PERI), Cd and to some extent Cu revealed to be the most severe polluting agents responsible for degrading the river sediment environment. When dealing with environmental studies, it is essential to study both contamination and pollution; and contaminants and pollutants. To effectively disseminate information about contamination and pollution, PLI (CLI) and PERI respectively are suitable indicators. Cadmium exhibited continuous regularity in its enrichment at all sampling sites; contributed most to the ecological risks and would be a potential toxic to the sediment dwelling organisms at $64 \%$ of the sites which demonstrated high toxicity risks due to its exposure. Some immediate sediment quality management strategies are needed to remediate and control river bed contamination. This study also demonstrated that rapid developmental activities can severely affect the ecology of the river. Presence of toxic elements at elevated levels in bed sediments indicates higher exposure risk to the benthic biota and other aquatic organisms of the river. The present investigation, along with some other reported literature [40], reinforces suggestion that contaminated sediments are significantly responsible for the deterioration in ecological conditions of the rivers worldwide. Sediments act as sink of the trace elements, which under altered physical and chemical conditions of the river can alternately turn into source of the same elements. These elements in dissolved form can become available to the free floating organisms of the river like fishes, and can ultimately enter into the human beings via food chain. The bioavailability of $\mathrm{Cd}$ and other elements which is differentially and sequentially determined is the next phase of our investigations along with identifying possible effects of polluted sediments on the biochemical aspects of the higher organisms. This study provided some valuable insights employing a combination 
of sediment assessment approach which can be constructive in designing and planning strategic sediment management programmes and conservation guidelines of the river basins.

\section{Acknowledgements}

Financial grant provided by the Council of Scientific and Industrial Research (CSIR), India, in the form of Junior and Senior Research Fellowships and contingency grant to the Kumar Manoj for carrying carry out the research work is deeply acknowledged.

\section{References}

[1] Harikumar, P.S., Nasir, U.P. and Rahman, M.P.M. (2009) Distribution of Heavy Metals in the Core Sediments of a Tropical Wetland System. International Journal of Environmental Science and Technology, 6, 225-232. http://dx.doi.org/10.1007/BF03327626

[2] Sekabira, K., Oryem, O.H., Basamba, T.A., Mutumba, G. and Kakudidi, E. (2010) Assessment of Heavy Metal Pollution in the Urban Stream Sediments and Its Tributaries. International Journal of Environmental Science and Technology, 7, 435-446. http://dx.doi.org/10.1007/BF03326153

[3] Mohiuddin, K.M., Zakir, H.M., Otomo, K., Sharmin, S. and Shikazono, N. (2010) Geochemical Distribution of Trace Metal Pollutants in Water and Sediments of Downstream of an Urban River. International Journal of Environmental Science and Technology, 7, 17-28. http://dx.doi.org/10.1007/BF03326113

[4] Sun, W., Sang, L. and Jiang, B. (2012) Trace Metals in Sediments and Aquatic Plants from the Xiangjiang River, China. Journal of Soils and Sediments, 12, 1649-1657. http://dx.doi.org/10.1007/s11368-012-0596-8

[5] Milenkovic, N., Damjanovic, M. and Ristic, M. (2005) Study of Heavy Metal Pollution in Sediments from the Iron Gate (Danube River), Serbia and Montenegro. Polish Journal of Environmental Studies, 14, 781-787.

[6] Begum, A., Ramaiah, M., Harikrishna, Khan, I. and Veena, K. (2009) Heavy Metal Pollution and Chemical Profile of Cauvery River Water. E-Journal of Chemistry, 6, 47-52. http://dx.doi.org/10.1155/2009/154610

[7] Prasad, M.B.K., Ramanathan, A.L., Shrivastav, S.K., Anshumali and Saxena, R. (2006) Metal Fractionation Studies in Surfacial and Core Sediments in the Achankovil River Basin in India. Environmental Monitoring and Assessment, 121, 77-102. http://dx.doi.org/10.1007/s10661-005-9108-2

[8] Palumbo-Roe, P., Wragg, J. and Banks, V.J. (2012) Lead Mobilisation in the Hyporheic Zone and River Bank Sediments of a Contaminated Stream: Contribution to Diffuse Pollution. Journal of Soils and Sediments, 12, 1633-1640. http://dx.doi.org/10.1007/s11368-012-0552-7

[9] Olubunmi, F.E. and Olorunsola, O.E. (2010) Evaluation of the Status of Heavy Metal Pollution of Sediment of Agbabu Bitumen Deposit Area, Nigeria. European Journal of Scientific Research, 41, 373-382.

[10] Suthar, S., Nema, A.K., Chabukdhara, M. and Gupta, S.K. (2009) Assessment of Metals in Water and Sediments of Hindon River, India: Impact of Industrial and Urban Discharges. Journal of Hazardous Materials, 171, 1088-1095. http://dx.doi.org/10.1016/j.jhazmat.2009.06.109

[11] Nicolau, R., Galera-Cunha, A. and Lucas, Y. (2006) Transfer of Nutrients and Labile Metals from the Continent to the Sea by a Small Mediterranean River. Chemosphere, 63, 469-476. http://dx.doi.org/10.1016/j.chemosphere.2005.08.025

[12] Dan’Azumi, S. and Bichi, M.H. (2010) Industrial Pollution and Heavy Metals Profile of Challawa River in Kanao, Nigeria. Journal of Applied Sciences in Environmental Sanitation, 5, 23-29.

[13] Kar, D., Sur, P., Mandal, S.K., Saha, T. and Kole, R.K. (2008) Assessment of Heavy Metal Pollution in Surface Water. International Journal of Environmental Science \& Technology, 5, 119-124. http://dx.doi.org/10.1007/BF03326004

[14] Nair, I.V., Singh, K., Arumugam, M., Gangadhar, K. and Clarson, D. (2010) Trace Metal Quality of Meenachil River at Kottayam, Kerala (India) by Principal Component Analysis. World Applied Sciences Journal, 9, 1100-1107.

[15] Harikumar, P.S. and Jisha, T.S. (2010) Distribution Pattern of Trace Metal Pollutants in the Sediments of an Urban Wetland in the Southwest Coast of India. International Journal of Engineering Science and Technology, 2, 840-850.

[16] Roy, D., Begam, S., Ghosh, S. and Jana, S. (2013) Calibration and Validation of HEC-HMS Model for a River Basin in Eastern India. ARPN Journal of Engineering and Applied Sciences, 8, 40-56.

[17] IRBMS (2012) Integrated River Basin Management Society. Newsletter, No. 38, Ganga.

[18] Ahdy, H.H.H. and Khaled, A. (2009) Heavy Metals Contamination in Sediments of the Western Part of the Egyptian Mediterranean Sea. Australian Journal of Basic and Applied Sciences, 3, 3330-3336.

[19] Han, Y.M., Du, P.X., Cao, J.J. and Posmentier, E.S. (2006) Multivariate Analysis of Heavy Metal Contamination in Urban Dusts of Xi'an, Central China. Science of the Total Environment, 355, 176-186. 
http://dx.doi.org/10.1016/j.scitotenv.2005.02.026

[20] Behera, P.K. (2006) Soil and Solid Waste Analysis: A Laboratory Manual. Dominant Publishers and Distributors, New Delhi.

[21] Walkley, A. and Black, I.A. (1934) An Examination of the Degtjareff Method for Dtermining Soil Organic Matter and a Proposed Modification of the Chromic Acid Titration Method. Soil Science, 37, 29-38. http://dx.doi.org/10.1097/00010694-193401000-00003

[22] Hseu, Z.Y. (2004) Evaluating Heavy Metal Contents in Nine Composts Using Four Digestion Methods. Bioresource Technology, 95, 53-59. http://dx.doi.org/10.1016/j.biortech.2004.02.008

[23] Hakanson, L. (1980) An Ecological Risk Index for Aquatic Pollution Control: A Sedimentological Approach. Water Research, 14, 975-1001. http://dx.doi.org/10.1016/0043-1354(80)90143-8

[24] Tomlinson, D.C., Wilson, J.G., Harris, C.R. and Jeffrey, D.W. (1980) Problems in Assessment of Heavy Metals in the Estuaries and the Formation of Pollution Index. Helgoland Marine Research, 33, 566-575.

[25] Sinex, S.A. and Helz, G.R. (1981) Regional Geochemistry of Trace Elements in Checapeake Bay Sediments. Environmental Geology, 3, 315-323. http://dx.doi.org/10.1007/BF02473521

[26] Sutherland, R.A. (2000) Bed Sediment-Associated Trace Metals in an Urban Stream, Oahu, Hawaii. Environmental Geology, 39, 611-627. http://dx.doi.org/10.1007/s002540050473

[27] Müller, G. (1979) Heavy Metals in the Sediment of the Rhine-Changes Seity. Umschau in Wissenschaft und Technik, 79, 778-783.

[28] Müller, G. (1981) The Heavy Metal Pollution of the Sediments of Neckars and its Tributary: A Stocktaking. Chemiker Zeitung, 105, 157-164.

[29] Wei, B.G., Jiang, F.Q., Li, X.M. and Mu, S.Y. (2010) Heavy Metal Induced Ecological Risk in the City of Urumqi, NW China. Environmental Monitoring and Assessment, 160, 33-45. http://dx.doi.org/10.1007/s10661-008-0655-1

[30] Li, X., Liu, L., Wang, Y., Luo, G., Chen, X., Yang, X., Gao, B. and He, X. (2012) Integrated Assessment of Heavy Metal Contamination in Sediments from a Coastal Industrial Basin, NE China. PLoS ONE, 7, e39690.

[31] Turekian, K.K. and Wedepohl, K.H. (1961) Distribution of the Elements in Some Major Units of the Earth’s Crust. Geological Society of America Bulletin, 72, 175-192. http://dx.doi.org/10.1130/0016-7606(1961)72[175:DOTEIS]2.0.CO;2

[32] Rath, P., Panda, U.C., Bhatta, D. and Sahoo, B.N. (2005) Environmental Quantification of Heavy Metals in the Sediments of the Brahmani and Nandira Rivers, Orissa. Journal of the Geological Society of India, 65, 487-492.

[33] Chakravarty, M. and Patgiri, A.D. (2009) Metal Pollution Assessment in Sediments of the Dikrong River, N.E. India. Journal of Human Ecology, 27, 63-67.

[34] MacDonald, D.D., Ingersoll, C.G. and Berger, T.A. (2000) Development and Evaluation of Consensus-Based Sediment Quality Guidelines for Freshwater Ecosystems. Archives of Environmental Contamination and Toxicology, 39, 20-31. http://dx.doi.org/10.1007/s002440010075

[35] Luo, W., Lu, Y., Wang, T., Hu, W., Jiao, W., Naile, J.E., Khim, J.S. and Giesy, J.P. (2010) Ecological Risk Assessment of Arsenic and Elements in Sediments of Coastal Areas of Northern Bohai and Yellow Seas, China. Ambio, 39, 367-375. http://dx.doi.org/10.1007/s13280-010-0077-5

[36] Fairey, R., Long, E.R., Roberts, C.A., Anderson, B.S., Phillips, B.M., Hunt, J.W., Puckett, H.R. and Wilson, C.J. (2001) An Evaluation of Methods for Calculating Mean Sediment Quality Guideline Quotients as Indicators of Contamination and Acute Toxicity to Amphipods by Chemical Mixtures. Environmental Toxicology and Chemistry, 20, 2276-2286. http://dx.doi.org/10.1002/etc.5620201021

[37] Puyate, Y.T., Rim-Rukeh, A. and Awatefe, J.K. (2007) Metal Pollution Assessment and Particle Size Distribution of Bottom Sediment of Orogodo River, Agbor, Delta State, Nigeria. Journal of Applied Sciences Research, 3, $2056-2061$.

[38] Kumar, S.P. and Edward, J.K.P. (2009) Assessment of Metal Concentration in the Sediment Cores of Manakudy Estuary, South West Coast of India. Indian Journal of Geo-Marine Sciences, 38, 235-248.

[39] Abu-Rukah, Y. and Ghrefat, H.A. (2001) Assessment of the Anthropogenic Influx of Metallic Pollutants in Yarmouk River, Jordan. Environmental Geology, 40, 683-692. http://dx.doi.org/10.1007/s002540000233

[40] Singh, V.K., Singh, K.P. and Mohan, D. (2005) Status of Heavy Metals in Water and Bed Sediments of River Gomti-A Tributary of the Ganga River, India. Environmental Monitoring and Assessment, 105, 43-67. http://dx.doi.org/10.1007/s10661-005-2816-9

[41] Beg, K.R. and Ali, S. (2008) Chemical Contaminants and Toxicity of Ganga River Sediments from Up and Downstream Area at Kanpur. American Journal of Environmental Sciences, 4, 362-366. http://dx.doi.org/10.3844/ajessp.2008.362.366 
[42] Hassan, F.M., Saleh, M.M. and Salman, J.M. (2010) A Study of Physicochemical Parameters and Nine Heavy Metals in the Euphrates River, Iraq. E-Journal of Chemistry, 7, 685-692. http://dx.doi.org/10.1155/2010/906837

[43] Mohiuddin, K.M., Ogawa, Y., Zakir, H.M., Otomo, K. and Shikazomo, N. (2011) Heavy Metals Contamination in Water and Sediments of an Urban River in a Developing Country. International Journal of Environmental Science and Technology, 8, 723-736. http://dx.doi.org/10.1007/BF03326257

[44] Jumbe, A.S. and Nandini, N. (2009) Heavy Metals Analysis and Sediment Quality Values in Urban Lakes. American Journal of Environmental Sciences, 5, 678-687. http://dx.doi.org/10.3844/ajessp.2009.678.687

[45] Chapman, P.M. (2007) Determining When Contamination Is Pollution-Weight of Evidence Determinations for Sediments and Effluents. Environment International, 33, 492-501. http://dx.doi.org/10.1016/j.envint.2006.09.001

[46] Yisa, J., Jacob, J.O. and Onoyima, C.C. (2012) Assessment of Toxic Levels of Some Heavy Metals in Road Deposited Sediments in Suleja, Nigeria. American Journal of Chemistry, 2, 34-37. http://dx.doi.org/10.5923/j.chemistry.20120202.08

[47] Rafiei, B., Bakhtiari, N.M., Hashemi, M. and Khodaei, A.S. (2010) Distribution of Heavy Metals around the Dashkasan Au Mine. International Journal of Environmental Research, 4, 647-654.

[48] Charkhabi, A.H., Sakizadeh, M. and Rafiee, G. (2005) Seasonal Fluctuation in Heavy Metal Pollution in Iran’s Siarhoud River: A Preliminary Study. Environmental Science and Pollution Research, 12, 264-270. http://dx.doi.org/10.1065/espr2005.06.270

[49] APHA (2005) Standard Methods for the Examination of Water and Wastewater Analysis. APHA-AWWA-WEF, Washington DC.

[50] CEBR (2013) Cebr’s World Economic League Table. Centre for Economics and Business Research, London.

[51] Amarasinghe, U.A., Sharma, B.R., Aloysius, N., Scott, C., Smakhtin, V. and de Fraiture, C. (2004) Spatial Variation in Water Supply and Demand Across River Basins of India. Research Report 83, International Water Management Institute, Colombo. 
Scientific Research Publishing (SCIRP) is one of the largest Open Access journal publishers. It is currently publishing more than 200 open access, online, peer-reviewed journals covering a wide range of academic disciplines. SCIRP serves the worldwide academic communities and contributes to the progress and application of science with its publication.

Other selected journals from SCIRP are listed as below. Submit your manuscript to us via either submit@scirp.org or Online Submission Portal.
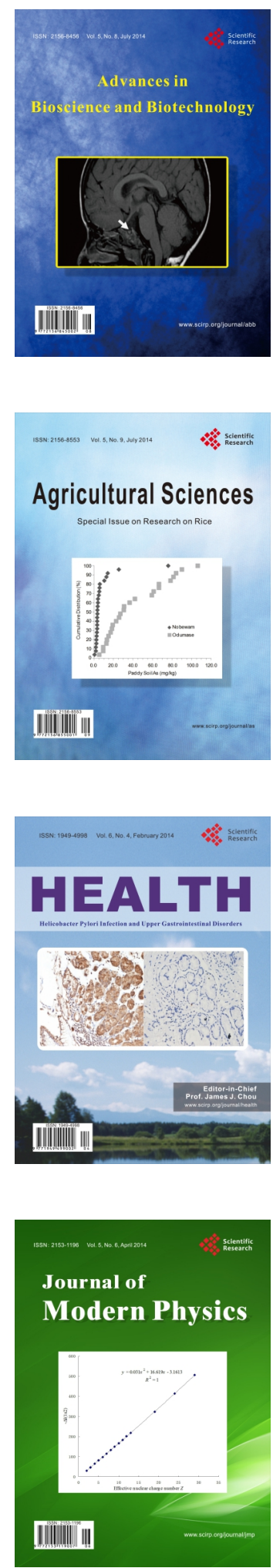
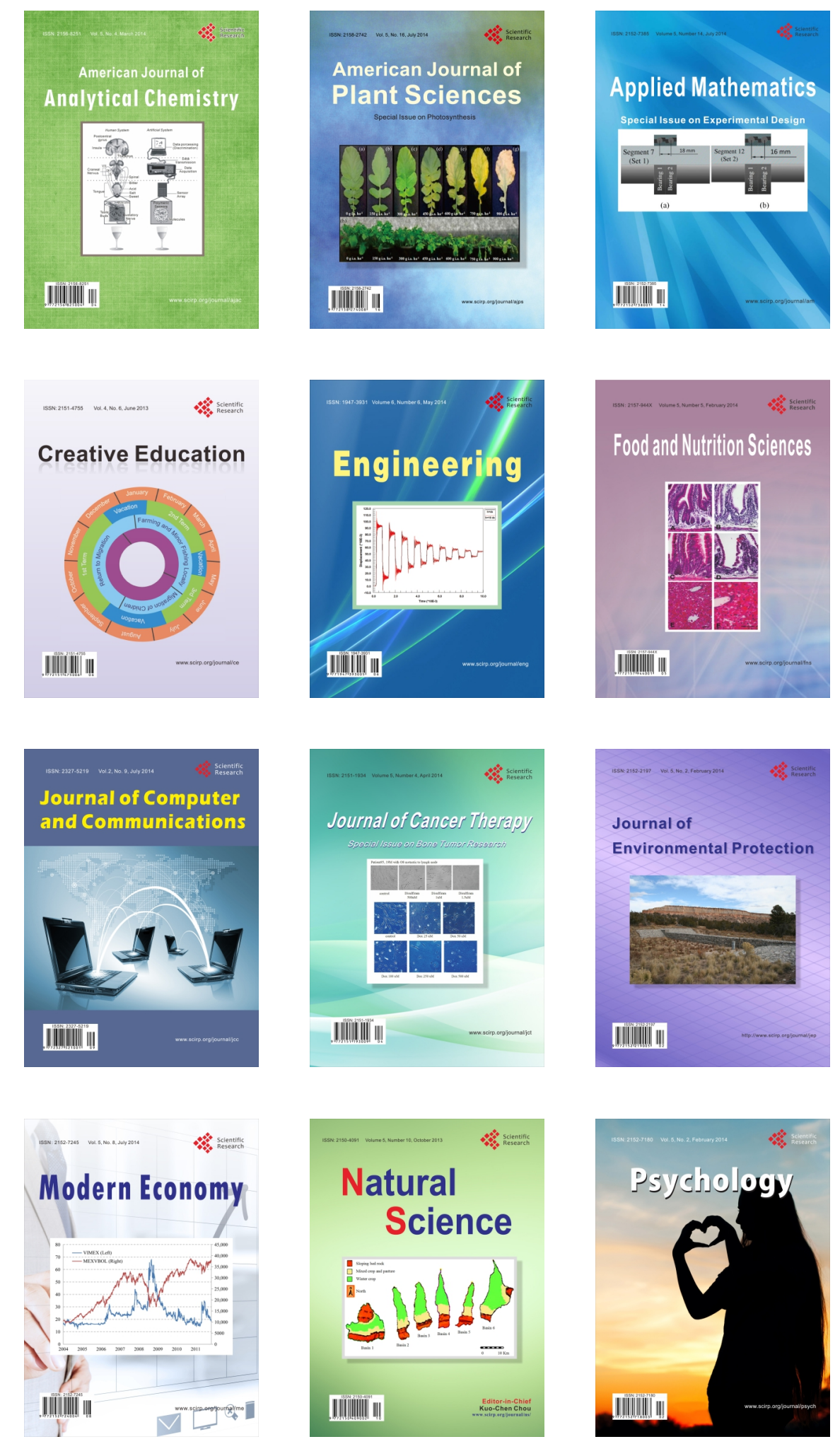